\title{
Searching Anti-Zika Virus Activity in 1H-1,2,3-Triazole Based Compounds
}

\author{
Willyenne M. Dantas ${ }^{1,2}$, Valentina N. M. de Oliveira ${ }^{3,4}$, Diogo A. L. Santos ${ }^{4}$, Gustavo Seabra ${ }^{4}$, Prem P. Sharma ${ }^{5}$, \\ Brijesh Rathi ${ }^{5}$ D, Lindomar J. Pena ${ }^{2, *}$ and Ronaldo N. de Oliveira ${ }^{1, *(D)}$
}

1 Department of Chemistry, Federal Rural University of Pernambuco, Recife 52171-900, Brazil; willyenne.dantas@ufrpe.br

2 Department of Virology, Aggeu Magalhães Institute (IAM), Oswaldo Cruz Foundation (Fiocruz), Recife 50670-420, Brazil

3 Instituto Federal de Educação Ciência e Tecnologia de Pernambuco, Campus Ipojuca, Ipojuca 55590-000, Brazil; valentinamelo@ipojuca.ifpe.edu.br

4 Department of Fundamental Chemistry, Federal University of Pernambuco, Recife 50740-540, Brazil; diogoalveslopessantos@gmail.com (D.A.L.S.); gustavo.seabra@gmail.com (G.S.)

5 Laboratory for Translational Chemistry and Drug Discovery, Department of Chemistry, Hansraj College, University of Delhi, Delhi 110007, India; premprakash.cr@gmail.com (P.P.S.); brijeshrathi@hrc.du.ac.in (B.R.)

* Correspondence: lindomar.pena@cpqam.fiocruz.br (L.J.P.); ronaldo.noliveira@ufrpe.br (R.N.d.O.); Tel.: +55-(81)-2123-7849 (L.J.P.); +55-(81)-3320-6317 (R.N.d.O.)

Citation: Dantas, W.M.; de Oliveira, V.N.M.; Santos, D.A.L.; Seabra, G.; Sharma, P.P.; Rathi, B.; Pena, L.J.; de Oliveira, R.N. Searching Anti-Zika Virus Activity in $1 H$-1,2,3-Triazole Based Compounds. Molecules 2021, 26, 5869. https://doi.org/10.3390/ molecules26195869

Academic Editor: Gian Cesare Tron

Received: 27 July 2021

Accepted: 22 September 2021

Published: 28 September 2021

Publisher's Note: MDPI stays neutral with regard to jurisdictional claims in published maps and institutional affiliations.

Copyright: (c) 2021 by the authors. Licensee MDPI, Basel, Switzerland. This article is an open access article distributed under the terms and conditions of the Creative Commons Attribution (CC BY) license (https:// creativecommons.org/licenses/by/ $4.0 /)$.
Abstract: Zika virus (ZIKV) is a mosquito-borne virus belonging to the Flaviviridae family and is responsible for an exanthematous disease and severe neurological manifestations, such as microcephaly and Guillain-Barré syndrome. ZIKV has a single strand positive-sense RNA genome that is translated into structural and non-structural (NS) proteins. Although it has become endemic in most parts of the tropical world, Zika still does not have a specific treatment. Thus, in this work we evaluate the cytotoxicity and antiviral activities of 14 hybrid compounds formed by $1 \mathrm{H}-1,2,3$-triazole, naphthoquinone and phthalimide groups. Most compounds showed low cytotoxicity to epithelial cells, specially the $\mathbf{3 b}$ compound. After screening with all compounds, $\mathbf{4 b}$ was the most active against ZIKV in the post-infection test, obtaining a 50\% inhibition concentration $\left(\mathrm{IC}_{50}\right)$ of $146.0 \mu \mathrm{M}$ and SI of 2.3. There were no significant results for the pre-treatment test. According to the molecular docking compound, $\mathbf{4 b}$ was suggested with significant binding affinity for the NS5 RdRp protein target, which was further corroborated by molecular dynamic simulation studies.

Keywords: Zika virus; cytotoxicity; $1 H$-1,2,3-triazoles; phthalimide; naphthoquinone; MD simulation

\section{Introduction}

Zika virus (ZIKV) is a Flavivirus that belongs to the Flaviviridae family. This epidemic arbovirus is transmitted mainly by the bites of infected mosquitos from the genus Aedes and, possibly, Culex [1]. The virus has icosahedral symmetry and its genome consists of a single strand of positive-sense RNA, which is translated into structural $(C, p r M, E)$ and non-structural (NS1, NS2A, NS2B, NS3, NS4A, NS4B, NS5) proteins [2]. ZIKV was first identified in 1947 when scientists discovered the then unknown virus from a febrile rhesus monkey used in yellow fever research in the Zika forest, Uganda [3]. After 60 years without major outbreaks, ZIKV was responsible for an epidemic in the Yap Islands in 2007 [4] and then in French Polynesia in 2012-2013 [5]. At the beginning of 2015, the first cases in Brazil were reported and the virus caused a serious epidemic resulting in over 200 thousand cases [6]. Several attributes contributed to ZIKV becoming endemic in Brazil, including the abundance of the mosquito vector, the deficiency of basic sanitation, inadequate housing conditions and the deficient public health policies to combat the virus [7].

The most common symptoms developed by patients infected with ZIKV are skin rash, low-grade fever, arthralgia, conjunctivitis, and headache. However, neurological disease 
of varying degrees of severity have also been reported, including some lethal cases [8,9]. One important neurological disorder associated with ZIKV infection is the Guillain-Barré syndrome, which affects mainly adults and is characterized by the destruction of the myelin sheath of neuronal cells [8]. Importantly, cases of microcephaly and other congenial defects, referred to as congenital Zika syndrome (CZS), have been categorically attributed to ZIKV infection [10]. Despite the severity of associated diseases and its endemicity in tropical areas of the globe, there are neither vaccines nor specific treatment to halt virus replication and alleviate patients' symptoms. Thus, the development of effective antivirals and vaccines alongside mosquito control strategies are extremely important for combating this important pathogen and preventing new epidemics.

Given their structural diversity, a wide range of biological activities have been explored for the development of therapies. These properties make it possible for these molecules to interact with protein sites and trigger actions at a cellular level. Further structural modification of these compounds may improve the performance of a specific biological activity [11]. Recent studies reported the action of some heterocycles against the Zika virus such as the already known chloroquine [12], sofosbuvir [13], ribavirin, and faviparivir [14], as well as new chemical entities, for example pyrrolo[2,3-d]pyrimidines [15]. A tremendous effort has been and is being invested in the development of effective molecules against ZIKV; however, there no approved anti-ZIKV drugs [16].

Nucleoside analogs are another class of antivirals that have been tested extensively against ZIKV due to their proven role in preventing the replication of RNA viruses. For instance, our research group has identified the thiopurine nucleoside analogue 6methylmercaptopurine riboside (6MMPr) as a potent inhibitor of ZIKV replication in cell culture [17]. To rationalize our strategy, we consider that phthalimide group is known for its anti-inflammatory activity, an important property in infection events. 1,4-Naphthoquinones have relevant cytotoxic activities. These two parts can be conjugated via click chemistry from organic azides and terminal alkynes generating a variety of $1 \mathrm{H}-1,2,3$-triazole compounds (Figure 1).

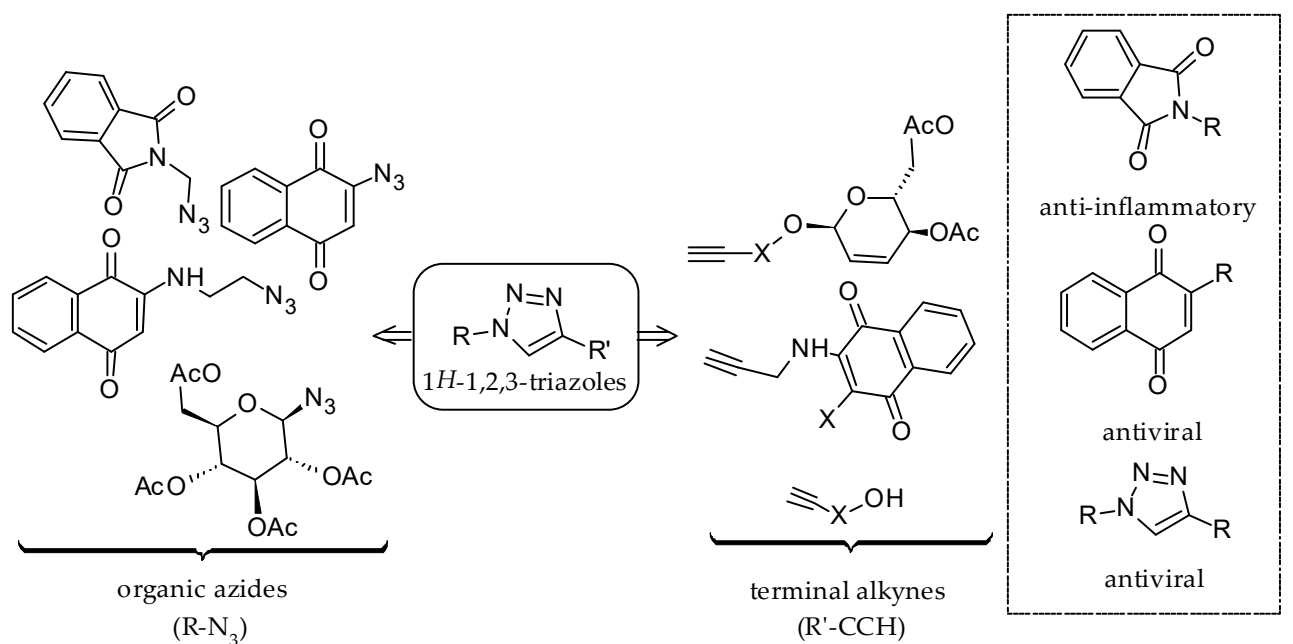

Figure 1. Strategy for molecular diversity towards antiviral 1H-1,2,3-triazoles.

These three classes of compounds, namely 1,4-naphthoquinone, phthalimide and 1,2,3-triazole inspired our research. These moieties have biological activities against several infections [18-20], including ZIKV [21,22]. Our group has synthesized several heterocycle derivatives and tested their activities against human cancer cell lines [23-25]. The compounds 1-7 (see Figure 2), that contain these cited heterocycles, and will be evaluated, were previously synthesized by our research group, except for compound 5a [25-27]. Here, we expand our initial efforts and evaluate their cytotoxicity to epithelial cells and their antiviral activity against ZIKV. 


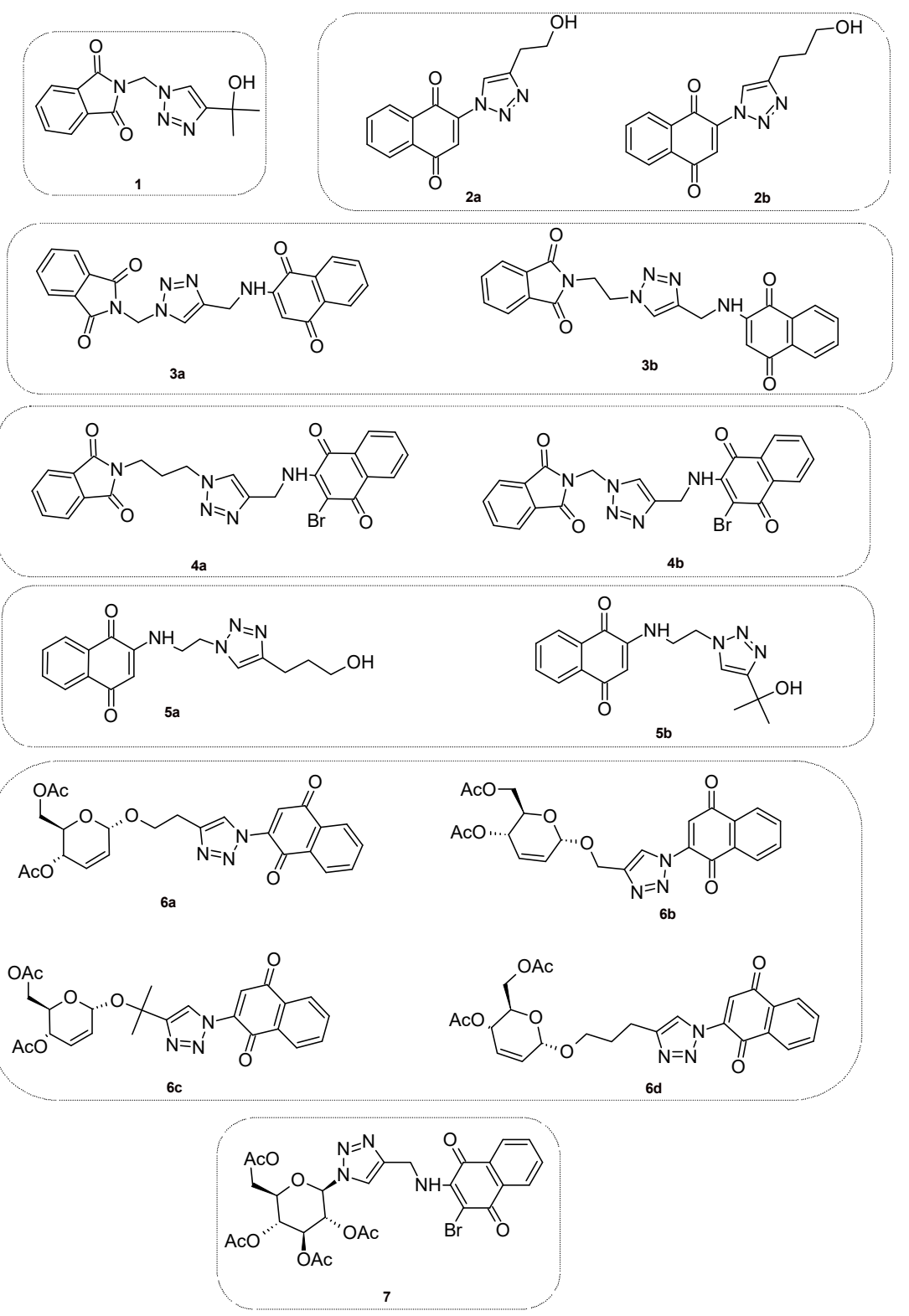

Figure 2. 1H-1,2,3-Triazole derivatives 1-7 tested against ZIKV.

\section{Results}

2.1. Synthesis of the Compounds $\mathbf{1 - 7}$

Compounds 1-7 (Figures 2 and 3, Table 1) were prepared according to the methodologies described previously by our research group [25-27]. Only the compound, 5a, is a new compound. All compounds were characterized through infrared (IR) and nuclear magnetic resonance (NMR) analyses and yields between 62-95\% were obtained. For a better discussion of the results, the compounds were classified according to triazole-linked groups.

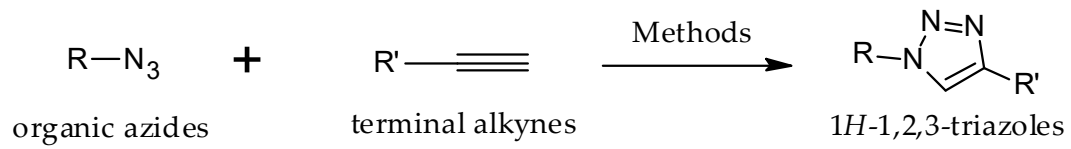

Figure 3. Synthesis of $1 H-1,2,3$-triazoles from organic azides and terminal alkynes. 
Table 1. Synthesis of $1 H-1,2,3-$ triazole derivatives 1-7.

\begin{tabular}{ccccc}
\hline Entry & Products & Methods & Yields, $\%$ & Reference \\
\hline 1 & $\mathbf{1}$ & A & 92 & {$[26]$} \\
2 & $\mathbf{2 a , b}$ & B & $85-95$ & {$[25]$} \\
3 & $\mathbf{3 a , b}$ & C & $70-95$ & {$[26]$} \\
4 & $\mathbf{4 a , b}$ & D & $70-88$ & {$[27]$} \\
5 & $\mathbf{5 a}$ & E & 90 & New compound \\
& $\mathbf{5 b}$ & E & 86 & {$[26]$} \\
6 & $\mathbf{6 a - d}$ & F & $62-85$ & {$[25]$} \\
7 & $\mathbf{7}$ & D & 85 & {$[27]$} \\
\hline
\end{tabular}

Method-A: DMF/CuI//Et 3 N/ultrasound $/ 30$ min.; Method-B: $\mathrm{CH}_{3} \mathrm{CN} / \mathrm{CuI} / 0^{\circ} \mathrm{C} / 12 \mathrm{~h} /$ absence of light; MethodC: $\mathrm{CH}_{3} \mathrm{CN} / \mathrm{CuI} /$ r.t. $/ 20$ h; Method-D: DMF/CuI/ $\mathrm{Et}_{3} \mathrm{~N} /$ r.t. $/ 60 \mathrm{~min}$; Method-E: DMSO/CuI/Et 3 N/r.t. $/ 2$ h; F: $\mathrm{CH}_{3} \mathrm{CN} / \mathrm{CuI} / 0^{\circ} \mathrm{C} / 12 \mathrm{~h}$.

\subsection{Cytotoxicity of Triazole Derivatives in Vero Cells}

The cytotoxicity of compounds 1-7 to Vero cells, an epithelial cell line derived from the kidney of an African green monkey, was tested using the 3-(4,5-dimethylthiazol-2-yl)-2,5diphenyltetrazolium bromide (MTT) method. Statistical analysis found $20 \%$ cytotoxicity concentration $\left(\mathrm{CC}_{20}\right)$ values between $8.87-527.20 \mu \mathrm{M}$ and $50 \%$ cytotoxicity concentration $\left(\mathrm{CC}_{50}\right)$ values from 38.01 to $1189 \mu \mathrm{M}$ for the tested compounds (Table 2). Based on $\mathrm{CC}_{20}$ values, which was the maximum concentration used for antiviral screening, $3 \mathbf{b}$ compound was the least toxic with a value of $527.2 \mu \mathrm{M}$. Compounds $\mathbf{2 a}$ and $\mathbf{2 b}$ were the most cytotoxic with values of $8.87 \mu \mathrm{M}$ and $9.89 \mu \mathrm{M}$, respectively. Toxic effects of triazole derivates showed dependence with structural modification. Treatment of cells with compounds linked to naphthoquinone $\mathbf{5 a}, \mathbf{b}$ and $\mathbf{6 a}-\mathbf{d}$ resulted in low cell viability, whose $\mathrm{CC}_{20}$ ranged between $21.18-74.85 \mu \mathrm{M}$. The results from compounds $3 a, 3 b$ and $4 a, 4 b$ ranged from 40.69 to $527.20 \mu \mathrm{M}$. Compounds $\mathbf{1}$ (phthalimide-triazole-alcohol) and 7 (sugar-triazoleamino-naphthoquinone) showed median results of $177.10 \mu \mathrm{M}$ and $119.10 \mu \mathrm{M}$, respectively. These results show that the presence of only naphthoquinone in the molecule reduces the values of cytotoxic concentration. The presence of phthalimide group or sugar increases the values of $\mathrm{CC}_{20}$ and $\mathrm{CC}_{50}$ (Table 2 and Supplementary Material: Figure S1).

Table 2. Cytotoxicity assay in Vero cells (CC20 and CC50).

\begin{tabular}{cccc}
\hline Compound & $\mathbf{C C}_{\mathbf{2 0}}(\boldsymbol{\mu M})^{\mathbf{1}}$ & $\mathbf{C C}_{\mathbf{5 0}}(\boldsymbol{\mu M})^{\mathbf{2}}$ & $\log \mathbf{P}^{\mathbf{3}}$ \\
\hline $\mathbf{1}$ & 177.10 & 680.10 & 1.44 \\
$\mathbf{2 a}$ & 8.87 & 38.01 & 0.99 \\
$\mathbf{2 b}$ & 9.89 & 38.81 & 1.26 \\
$\mathbf{3 a}$ & 55.28 & 469.80 & 2.21 \\
$\mathbf{3 b}$ & 527.20 & 1189.00 & 2.22 \\
$\mathbf{4 a}$ & 40.69 & 68.78 & 3.23 \\
$\mathbf{4 b}$ & 136.90 & 330.20 & 2.94 \\
$\mathbf{5 a}$ & 74.85 & 293.90 & 1.05 \\
$\mathbf{5 b}$ & 66.93 & 298.20 & 1.38 \\
$\mathbf{6 a}$ & 39.92 & 68.05 & 2.07 \\
$\mathbf{6 b}$ & 21.18 & 48.69 & 1.86 \\
$\mathbf{6 c}$ & 25.73 & 58.14 & 2.67 \\
$\mathbf{6 d}$ & 38.61 & 69.50 & 2.34 \\
$\mathbf{7}$ & 119.10 & 334.50 & 1.80 \\
$\mathbf{6 M M P r}$ & 60.5 & 291 & 0.55 \\
\hline
\end{tabular}

${ }^{1} \mathrm{CC}_{20}(20 \%$ cytotoxic concentration) refers to compound concentration that causes a $20 \%$ reduction in cell viability.

${ }^{2} \mathrm{CC}_{50}(50 \%$ cytotoxic concentration) refers to compound concentration that causes a $50 \%$ reduction in cell viability.

${ }^{3}$ The $\log \mathrm{P}$ (the logarithm of the octanol-water partition coefficient): was calculated using the Molinspiration molecular property (http://www.molinspiration.com). ${ }^{4}$ See reference [17].

The cytotoxicity of phthalimide-amino-naphthoquinone-triazoles $3 \mathbf{a}, 3 \mathbf{b}$ and $4 \mathbf{a}, 4 \mathbf{b}$ showed dependence with the size of the alkyl chain and presence/absence of the bromine at the naphthoquinone moiety. 
For instance, the compounds $3 a$ (short alkyl chain, $\mathrm{CC}_{20}=55.28 \mu \mathrm{M}$ ) and $4 \mathbf{a}$ (long alkyl chain and bromine, $\mathrm{CC}_{20}=40.69 \mu \mathrm{M}$ ) were most cytotoxic than compound $3 \mathrm{~b}$ (long alkyl chain, $\mathrm{CC}_{20}=527.20 \mu \mathrm{M}$ ) and $\mathbf{4 b}$ (short alkyl chain and bromine, $\mathrm{CC}_{20}=136.90 \mu \mathrm{M}$ ). With these data, we observed that the size of the chain and the presence of the bromine atom are decisive for the $\mathrm{CC}_{20}$ results. Perhaps the access of the compounds to the cell change accord to these structural differences and chemical properties, as with hydrogen-bond interaction.

In compound 7 , the phthalimide group was exchanged for glucose from compound $4 \mathbf{b}$ and no major changes were found in $\mathrm{CC}_{20}(119.00 \mu \mathrm{M})$.

In general, the presence of phthalimide and/or amino-naphthoquinone groups made the molecules less cytotoxic, to mention some comparisons: (i) $\mathbf{1}(177.10 \mu \mathrm{M})$ and $\mathbf{2 a}, \mathbf{2 b}$ (8.87-9.89 $\mu \mathrm{M}$ ): 2-triazole-naphthoquinone is more toxic than phthalimide; (ii) $\mathbf{2} \mathbf{a}, \mathbf{2} \mathbf{b}$ and 6a-d (21.18-39.92 $\mu \mathrm{M})$, and 5a, 5b (74.85-66.93 $\mu \mathrm{M})$ : 2-amino-alkyl-naphthoquinone is less toxic than 2-triazole-naphthoquinone; (iii) $5 \mathbf{a}, \mathbf{5 b}$ with $\mathbf{3 b}, \mathbf{4 b}(527.20-136.90 \mu \mathrm{M})$ : the presence of phthalimide group decrease the cytotoxicity.

\subsection{Screening of Triazole Derivates}

The antiviral activities of the compounds were evaluated by infecting Vero cells with ZIKV and then treating them with the testing molecules. Virus titer in the supernatants of treated wells and its comparison with the negative (cell + virus) and the positive 6-methylmercaptopurine riboside (6MMPr) controls allowed for the determination of the antiviral effect. Only compound $\mathbf{4 b}$ was found to result in a statistically significant reduction in viral titer (Figure 4).

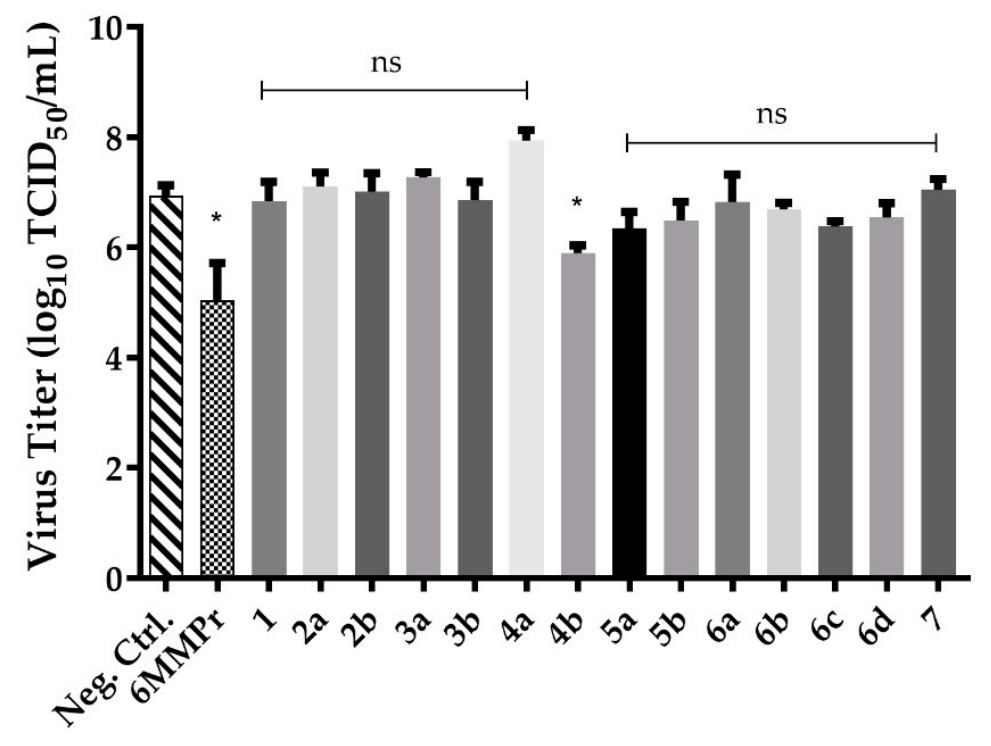

\section{Triazole derivates $\mathrm{CC}_{20}(\mu \mathrm{M})$}

Figure 4. Graphic result of all triazole derivates in the screening test for anti-ZIKV activity. The screening test was made for post-infection with ZIKV MOI 0.1 and treated with $\mathrm{CC}_{20}$ values from heterocyclic compounds discovered in the cytotoxicity test. After five days, the supernatant was collected and titrated by TCID 50 method. The experiment was conducted in triplicates and values are the mean and the standard deviation (SD). In the GraphPad Prism program, Dunnett's ANOVA analysis was used to determinate the best compounds comparing with control. * = significative; ns = not statistically significant for $p<0.05$.

According to the post-infection test performed, compound $4 \mathrm{~b}$ proved to be effective in inhibiting the virus at the lowest concentration used. The \% viral inhibition showed in Table 3, demonstrates that at $17.11 \mu \mathrm{M}(96.8 \%)$ 4b was most effective than $6 \mathrm{MMPr}$ at $7.56 \mu \mathrm{M}$ (81.1\%). Then, using less compound $\mathbf{4 b}$ yielded significant results in inhibiting ZIKV. 
Table 3. \% Viral Inhibition.

\begin{tabular}{cccccc}
\hline Compound & \multicolumn{2}{c}{$\mathbf{4 b}$} & \multicolumn{2}{c}{ 6MMPr } \\
\hline Concentration $(\boldsymbol{\mu M})$ & $\begin{array}{c}3 \text { d.p.i. } \\
\mathbf{\%}\end{array}$ & $\begin{array}{c}\mathbf{5} \text { d.p.i } \\
\mathbf{\%}\end{array}$ & $\begin{array}{c}\text { Concentration } \\
(\boldsymbol{\mu} \mathbf{M})\end{array}$ & $\begin{array}{c}\mathbf{3} \text { d.p.i. } \\
\mathbf{\%}\end{array}$ & $\begin{array}{c}\mathbf{5} \text { d.p.i. } \\
\mathbf{\%}\end{array}$ \\
\hline $\mathrm{CC}_{20}=136.90$ & 94.9 & 97.5 & 60.50 & 99.8 & 99.7 \\
$\mathrm{CC}_{20} / 2=68.45$ & 85.6 & 93.7 & 30.25 & 54.4 & 96.8 \\
$\mathrm{CC}_{20} / 4=34.23$ & 85.8 & 90.8 & 15.13 & 42.7 & 95.1 \\
$\mathrm{CC}_{20} / 8=17.11$ & 88.8 & 96.8 & 7.6 & -93.4 & 81.1 \\
\hline
\end{tabular}

${ }^{1}$ d.p.i.: days post-infection. ${ }^{*}$ The negative sign refers to increased virus titer compared to control.

\subsection{Pre-Treatment with Compound $\mathbf{4 b}$}

Since compound $\mathbf{4 b}$ was the only one in the series with activity against ZIKV, further experiments were conducted to elucidate its mechanism of action in cells that were pretreated. To this, cells were pre-treated with varying concentrations of compound $\mathbf{4 b}$, washed, and then infected with ZIKV. The concentrations used were chosen with the aim to preserve cellular viability and, thus, the maximum concentration was the previously determined $\mathrm{CC}_{20}$ value $(136.90,68.45,34.22$ and $17.11 \mu \mathrm{M})$. There was no significant change in virus titers when compared with negative control (cells + virus, untreated) (Figure 5), suggesting that compound $\mathbf{4 b}$ cannot prevent the entry of ZIKV into Vero cells.

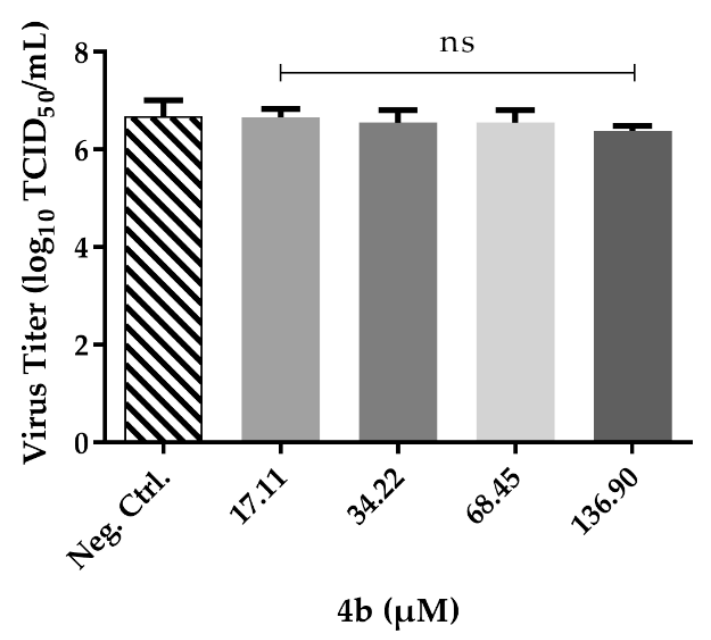

Figure 5. Graphic result for compound $\mathbf{4 b}$ in the pre-treatment test to ZIKV. Vero cells in a 48 -well cell plate were treated with $\mathbf{4 b}$ in different concentrations and after $1 \mathrm{~h}$ the supernatant was discarded. Cells were washed with PBS 1X, ZIKV MOI 0.1 was inoculated, and the plate was incubated again. After five days, the supernatant was collected and titrated by $\mathrm{TCID}_{50}$ method. The experiment was conducted in triplicates and values are the mean and the SD. In the GraphPad Prism program, Dunnett's ANOVA analysis was used to determinate the best concentrations comparing with control. ns $=$ not statistically significant for $p<0.05$.

\subsection{Post-Infection Studies of Compound $\mathbf{4 b}$}

We then investigated the activity of compound $4 \mathrm{~b}$ after ZIKV infection in cells. As already noted in the screening test, $4 \mathbf{b}$ reduced ZIKV growth to levels similar to 6MMPr, a positive control previously described by our group [17]. As in the pre-treatment test, four different concentrations were used, with the maximum being $\mathrm{CC}_{20}(136.90,68.45,34.22$ and $17.11 \mu \mathrm{M})$. According to the statistical analysis (Figure 5), $\mathbf{4 b}$ inhibits the growth of the virus at all concentrations used, especially in the highest one. It is worth highlighting the constant decrease in the viral titer, even in lower concentrations, while the positive control $6 \mathrm{MMPr}$ reduces it only in the highest concentrations. The $4 \mathrm{~b}$ half maximal inhibitory concentration $\left(\mathrm{IC}_{50}\right)$ and selectivity index (SI) was $146.0 \mu \mathrm{M}$ and 2.3, respectively (Table 4). 
Table 4. Results for post-infection test with 6MMPr and $4 \mathbf{b}$.

\begin{tabular}{cccc}
\hline & IC $_{\mathbf{5 0}}{ }^{\mathbf{1}}(\boldsymbol{\mu M})$ & SI $^{\mathbf{2}}$ & \% Viral Inhibition \\
\hline $\mathbf{4 b}$ & 146.0 & 2.3 & 91.1 \\
$\mathbf{6 M P r}$ & 24.5 & 11.9 & 97.8 \\
\hline
\end{tabular}

${ }^{1}$ IC50 (50\% inhibition concentration) refers to compound concentration that caused a 50\% inhibition in virus replication. ${ }^{2}$ SI (selectivity index) refers to the ratio between the $\mathrm{CC}_{50}$ and $\mathrm{IC}_{50}$ values.

The treatment time of the compounds for three days post-infection (d.p.i.) and five days post-infection (Figure 6) was also assessed; 6MMPr prevents the growth of the virus in both cases, but with a noticeable decrease if the treatment is longer. Compound $4 \mathbf{b}$ continues to behave similarly in both situations, decreasing the viral titer at all concentrations and at both times of treatment, suggesting that its antiviral activity lasts longer than the reference drug used in our tests (see Table S1). Statistical analysis compared the concentrations of each compound at each collection time ( 3 d.p.i. and 5 d.p.i.) with a $t$-test.
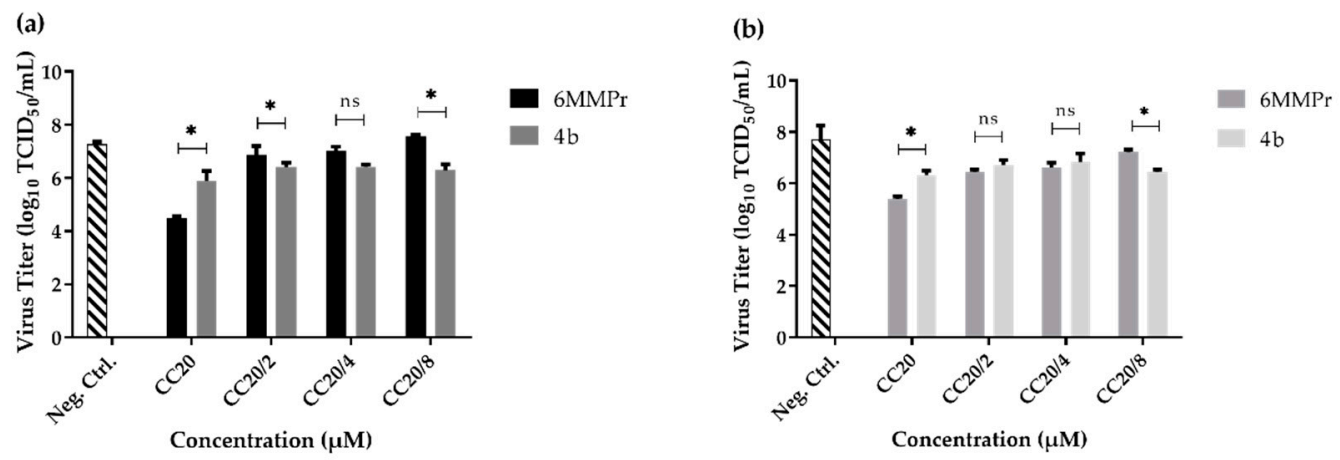

Figure 6. Comparison of anti-ZIKV activity between 6MMPr and $4 \mathrm{~b}$ after three- and five-days post-infection (d.p.i.). $6 \mathrm{MMPr}$ and compound $\mathbf{4 b}$ were submitted to a post-infection test when Vero cells was infected with ZIKV at MOI 0.1 for $2 \mathrm{~h}$ then treated with compounds. Concentrations used in the test corresponded to $\mathrm{CC}_{20}(4 \mathbf{b}=136.90 \mu \mathrm{M} ; 6 \mathrm{MMPr}=60.50 \mu \mathrm{M}), \mathrm{CC}_{20} / 2(4 \mathbf{b}=68.45 \mu \mathrm{M}$; $6 \mathrm{MMPr}=30.25 \mu \mathrm{M}), \mathrm{CC}_{20} / 4(4 \mathbf{b}=34.22 \mu \mathrm{M} ; 6 \mathrm{MMPr}=15.13 \mu \mathrm{M})$ and $\mathrm{CC}_{20} / 8(4 \mathbf{b}=17.11 \mu \mathrm{M}$; $6 \mathrm{MMPr}=7.56 \mu \mathrm{M})$. The experiment was done in triplicates and values are the mean and the SD. Statistical analysis was made between compounds using t-test on GraphPad Prism program. * = significative; $\mathrm{ns}=$ not statistically significant for $p<0.05$. (a) 3 d.p.i. from both compounds. (b) 5 d.p.i. from both compounds.

\subsection{Molecular Docking}

After discarding the hypothesis that $\mathbf{4 b}$ acts via a viral entry process and confirming instead that the viral inhibition of compound $4 \mathrm{~b}$ occurs in some stage of Zika replication, an investigation of the possible binding site was conducted. The compound, $6 \mathrm{MMPr}$, used as a reference drug, is a riboside analogue, so it was speculated its action would interfere with the RNA processing machinery of the virus. The two viral proteins that bind to RNA are NSP3 helicase and the NS5 RdRp proteins; PDB ID: 6MH3 and PDB ID: 5U04, respectively, were selected to predict the potential target of hit compound $\mathbf{4 b}$ through extensive in-silico studies.

The RdRp protein has several missing residues on many locations as depicted in Table S1 (Supporting Information). These missing residues were filled in the form on loops by Modeller. Among the 9 models, a top model (model 9) was selected based on the ERRAT score, PROSA, Verify 3D, and Procheck (Table S2, entry 9). The ERRAT score, PROSA, and Verify 3D score of selected models were measured as $-70.5882,-7.69$, and 84.95, respectively. The model 4 with an ERRAT score of 70.7612 was excluded because of poor $<80 \%$ Verify 3D score (Table S2, entry 4 ). The selected model has only $1.1 \%$ residues in a disallowed region (Table S2, entry 9), which included only 6 residues, Asp346, Ser406, Glu415, Ala537, Arg601, and Lys688, as depicted in Figure S2. Compound 4b in complex 
with the helicase $(6 \mathrm{MH} 3)$ protein showed docking score, XP Gscore, and binding free energy values of $-3.481 \mathrm{kcal} / \mathrm{mol},-3.481 \mathrm{kcal} / \mathrm{mol}$ and $-47.11 \mathrm{kcal} / \mathrm{mol}$, respectively. On the other hand, compound $\mathbf{4 b}$ complexed with the RdRp (5U04) protein displayed a docking score, XP Gscore, and binding free energy of $-5.348 \mathrm{kcal} / \mathrm{mol},-5.348 \mathrm{kcal} / \mathrm{mol}$ and $-52.91 \mathrm{kcal} / \mathrm{mol}$, respectively. In $4 \mathrm{~b}$-helicase complex, compound $4 \mathrm{~b}$ interacted to the binding site residues through H-bond (Asn463, Arg462), halogen bond (Trp403, Lys419), salt bridge interaction (Lys358), and pi-cation interaction (Lys419), as represented in Figure 7A. Likewise, in $\mathbf{4 b}$-RdRp complex, compound $\mathbf{4 b}$ revealed interactions through H-bond (Asp665, Ile799, Arg731), salt bridge interaction (Arg739), halogen bond (Arg731), and pi-pi interaction (Tyr609, Trp797), which are presented in Figure 7B. Molecular docking results suggested that compound $4 \mathrm{~b}$ possesses strong binding affinity towards RdRp protein over the helicase.

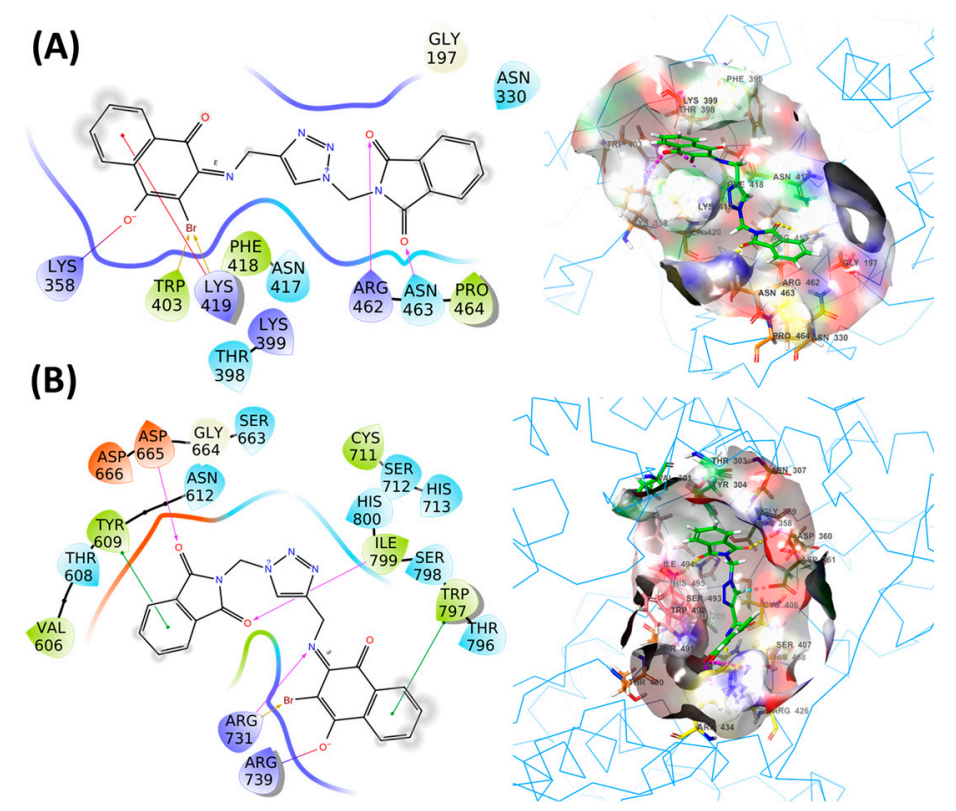

Figure 7. 2D-3D diagram of ligand-protein complex. (A) $4 \mathbf{b}$-helicase (6MH3) complex. (B) $4 \mathbf{b}-\mathrm{RdRp}$ (5U04) complex.

Next, MD simulation for 100 ns was performed to analyse the stability of the compound $4 \mathbf{b}$ within the binding pocket of both proteins, helicase and RdRp. In $4 \mathbf{b}$-helicase complex, protein $C \alpha-R M S D$ reached stability within $10 \mathrm{~ns}$ and the results are showcased in Figure 7. The RMSD of compound $4 \mathrm{~b}$ achieved stability nearby $28 \mathrm{~ns}$ and sustained up to $70 \mathrm{~ns}$. Afterwards, RMSD of $4 \mathrm{~b}$ became unstable and escaped from the binding pocket as indicated by the remarkably high RMSD and trajectory analysis (Figure 8). The ligand RMSF showed that its each atom fluctuated more than $6 \AA$, as presented in Figure S3a. The interaction with water may be responsible for the instability of compound $\mathbf{4 b}$, as displayed in Figure S3b.

On other hand, protein C $\alpha$-RMSD of $4 \mathbf{b}$-RdRp complex, stabilized within $10 \mathrm{~ns}$ and remained stable throughout the simulation period (100 ns) as presented in Figure 8. Compound $4 \mathrm{~b}$ RMSD suggested the structural and conformational stability, where fluctuation was observed within an acceptable range, $3 \AA$ (Figure 9A). Each atom of the compound $4 \mathbf{b}$ fluctuated within $3.5 \AA$ (Figure 9B). Compound $4 \mathbf{b}$ showed interactions with residues Tyr609, Trp797, Arg731, and Ile799 and thus supported docking results (Figure 9C). The Ramachandran mapping of compound $4 \mathbf{b}-\mathrm{RdRp}$ complex after MD simulation showed only $0.6 \%$ (Asn454, Glu695, and Trp748) residues in the disallowed region for the protein RdRp, which indicated good stereo-chemical geometry of the residues, as presented in Figure S4. 


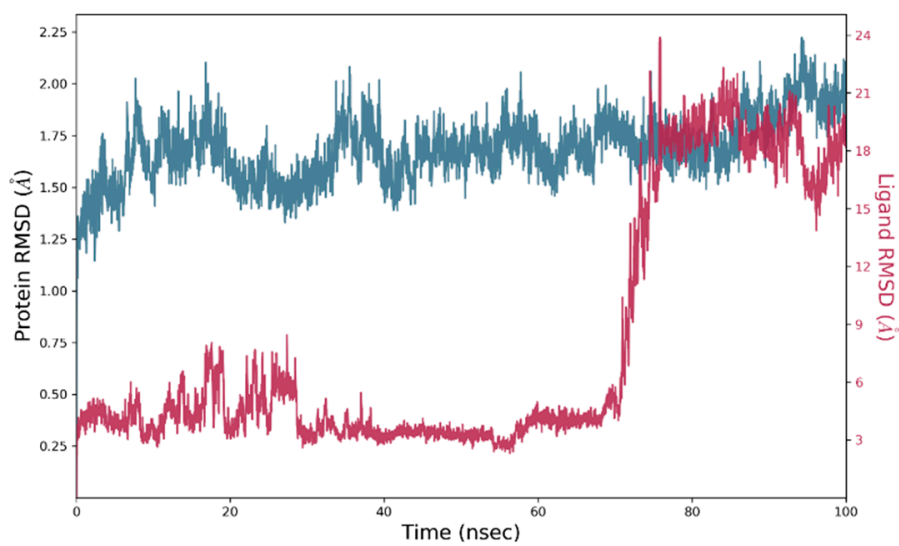

Figure 8. RMSD plot obtained for 4b-helicase (6MH3) complex: protein $\mathrm{C} \alpha$ and compound $4 \mathbf{b}$ RMSD shown in blue and red color, respectively.
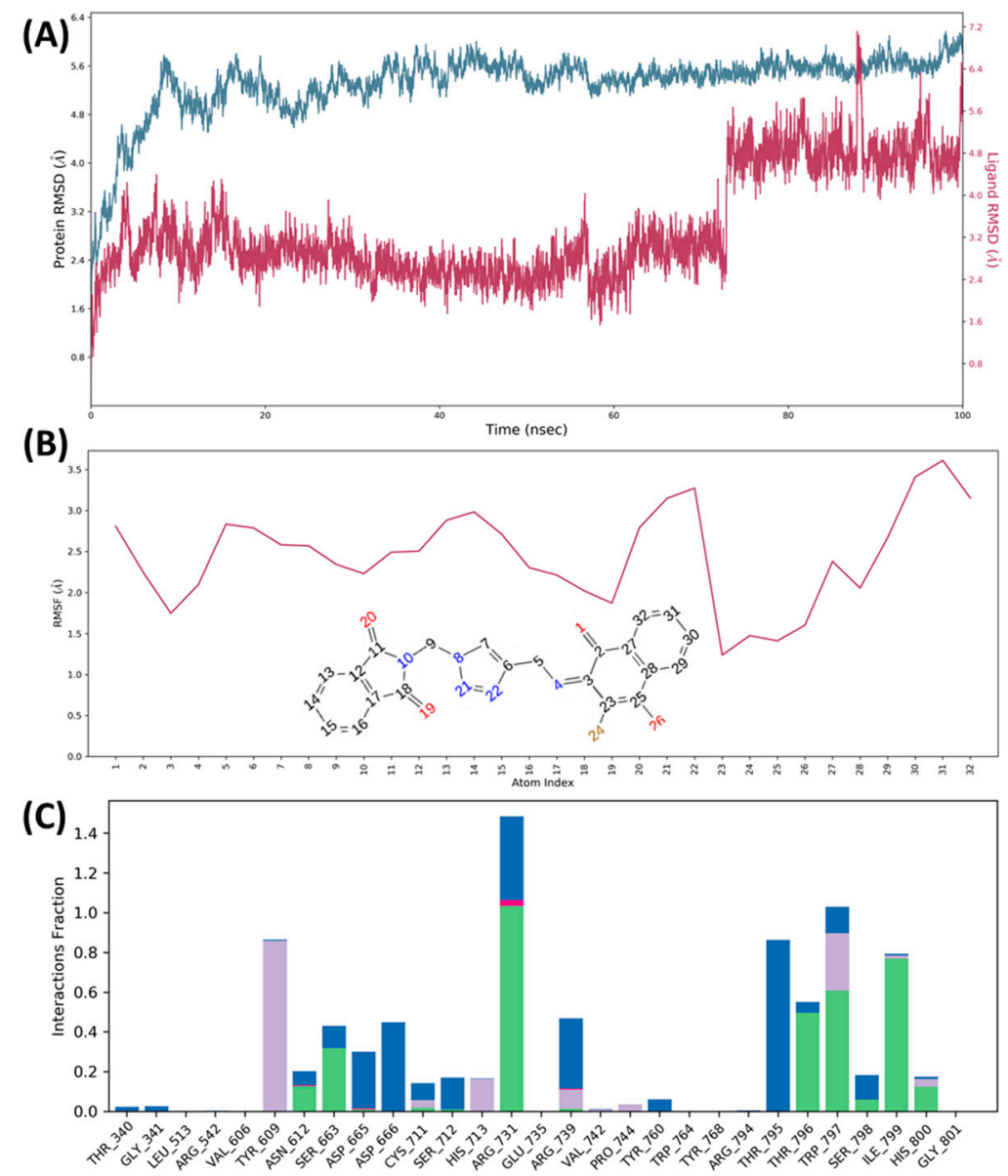

Figure 9. Molecular dynamics of $4 \mathrm{~b}-\mathrm{RdRp}$ (5U04) complex. (A) RMSD plot obtained for protein $\mathrm{C} \alpha$ and compound $\mathbf{4 b}$ shown in blue and red colour, respectively; (B) Ligand RMSF-fluctuations of each atom of compound $\mathbf{4 b}$ with respect to the protein; (C) Histogram plot showed interacting residues with compound $\mathbf{4 b}$ during MD simulation (H-bond: green, hydrophobic: grey, salt bridge interaction: pink, and water bridge interaction: blue).

\section{Discussion}

The search for effective treatments to combat symptoms and protect against ZIKV remains in progress, since there are no options available in the market. This work explored the potential of synthetic compounds in the search of viable treatment options against this devasting virus. 
According to the structural analysis of the compounds, some aspects related to the cytotoxic effect on Vero cells were highlighted. The compounds $\mathbf{2 a}$ and $\mathbf{2 b}$ (naphthoquinonetriazole-alcohol), whose cell viability results were more cytotoxic based on their $\mathrm{CC}_{20}$ value, presents the 1,4-naphthoquinone directly linked with $1 H$-1,2,3-triazole nucleus; on the other hand, in general, 2-amino-1,4-naphthoquinone decrease the toxicity level [27]. We believe that some conformational factor hydrophobic effects are present. Michael acceptor group ( $\mathbf{3 a} / \mathbf{3 b})$, and "halogen bond"-bromide- $(\mathbf{4} \mathbf{a} / \mathbf{4 b})$ can help with proteinligand complex interactions. All these factors can promote different results in cytotoxicity. The $4 \mathrm{a}$ cytotoxicity is likely due to this compound being more lipophilic $(\log \mathrm{P}=3.23$, Table 2) and may accumulate in the cell membrane with toxic consequences. This effect is shown in CC50 $(4 \mathbf{a}=68.78 \mu \mathrm{M})$. The phthalimide group, represented by 4-phenyl-1[2-(phthalimido-2-yl)ethyl]-1- $H$-1,2,3-triazole, showed low cytotoxicity for macrophages (peritoneal and J774A.1) and fibroblast cells [28].

Naphthoquinone-triazoles 6a-d linked to carbohydrates decreased the cytotoxicity, i.e., at $50 \mu \mathrm{M}$ they maintained cell viability around $80 \%$, except for $6 \mathbf{b}$. The aminonaphthoquinone-triazoles $5 \mathbf{a}$ and $\mathbf{5 b}$ behaved contrarily compared to $\mathbf{2 a}, \mathbf{2 b}$ and $\mathbf{6 a - d}$, being less cytotoxic, with cells remaining viable until the concentration of $400 \mu \mathrm{M}$.

Naphthoquinone compounds have a variety of activities described in the literature, including cytotoxicity in Vero cells. Gonzaga et al. (2019) used the MTT method to test the cytotoxicity of compounds derived from bis-naphthoquinones [21]. In general, the presence of the group, even in duplicate, does not increase cytotoxicity to Vero cells.

The screening reveals little or no action of the compounds 1-7 against ZIKV, except for $4 \mathbf{b}$, which was the only one with statistically significant results when compared to the non-treated control. Pre-treatment and post-infection tests were performed with $4 \mathrm{~b}$ to elucidate the possible mechanism of action and determine the $\mathrm{IC}_{50}$ and $\mathrm{SI}$ of values, $146.0 \mu \mathrm{M}$ and 2.3 , respectively. The results indicate that the compound $4 \mathrm{~b}$ probably acts in some stage of the virus replication after it has entered the cell. Overall, compound $\mathbf{4 b}$ exhibited significant anti-ZIKV activity without any apparent cytotoxicity.

Lima et al. (2019) tested triazole compounds against ZIKV with Vero cells. The method used was MTT in both analyses, thus verifying the viability of the cells in the tests. Lima's triazole series showed high cytotoxicity. The antiviral activity were the best ZIKV inhibitors, considering at least $50 \%$ of cell viability [22].

The analysis with the compound-based $1 H-1,2,3$-triazoles strengthens the principle that the presence of nitrogen groups increases the biological activity. The structural modification of the tested groups driven by in-silico techniques helped us to understand the negative response of the tested compounds against ZIKV, as well as the improvement of the $4 \mathrm{~b}$ response in viral inhibition.

Concerning the docking score, XP Gscore and binding free energy, compound $4 \mathbf{b}$ was suggested with a significant binding affinity towards RdRp protein when compared with helicase. These results were further corroborated by MD simulation studies. However, validation experiments are necessary before concluding the possible target for the hit compound $\mathbf{4 b}$.

\section{Materials and Methods}

\subsection{Chemistry}

Drugs: the compounds 1-7 (Figure 1) were synthesized by our research group. The formation of the triazole derivatives was carried out by copper(I)-catalysed azide-alkyne cycloaddition ( $\mathrm{CuAAC})$ through the reaction between phthalimide-azide or naphthoquinoneazide and 2,3-unsaturated glycosides or alkynyl alcohols. The synthesis of 2,3-unsaturated glycosides $\mathbf{6 a}-\mathbf{d}$ was carried out using the montmorillonite K-10/iron(III) chloride hexahydrate catalysis described by Melo et al. (2015) [25].

The new compound 5a was synthesized using Method $\mathrm{E}$ (Table 1) [26]. The ${ }^{1} \mathrm{H}$ and ${ }^{13} \mathrm{C}$ NMR are showed in the Figures S5 and S6. Characterization of 2-[2-(4-(3-Hydroxypropyl)1H-1,2,3-triazol-1-yl)]-ethylamino-1,4-naphthoquinone (5a): Yield $=90 \%$; red solid; $\mathrm{Mp}$ 
143-145 ${ }^{\circ} \mathrm{C} .{ }^{1} \mathrm{H}$ NMR (400 MHz, DMSO-d 6 ): $\delta$ 7.98-7.92 (m, 2H, $\left.\mathrm{H}_{\mathrm{Naph}}\right), 7.87\left(\mathrm{~s}, 1 \mathrm{H}, \mathrm{H}_{\text {Triaz }}\right)$, 7.84-7.72 (m, 2H, H $\mathrm{Naph}_{\text {) }}, 7.49$ (br s, 1H, NH), 5.70 (s, 1H, H-3 ${ }_{\mathrm{Naph}}$ ), 4.54 (t, 2H, J = 6.0 Hz, $\left.\mathrm{CH}_{2} \mathrm{~N}_{\text {Triaz }}\right), 4.39(\mathrm{t}, 1 \mathrm{H}, J=5.0 \mathrm{~Hz}, \mathrm{OH}), 3.66-3.64\left(\mathrm{~m}, 2 \mathrm{H}, \mathrm{CH}_{2} \mathrm{NH}\right), 3.40\left(\mathrm{~m}, 2 \mathrm{H}, \mathrm{CH}_{2} \mathrm{OH}\right)$, $2.60\left(\mathrm{~m}, 2 \mathrm{H}, \mathrm{CH}_{2}-\mathrm{C}_{\text {Triaz }}\right), 1.70\left(\mathrm{~m}, 2 \mathrm{H}, \mathrm{CH}_{2}\right) .{ }^{13} \mathrm{C}$ NMR $\left(100 \mathrm{MHz}, \mathrm{DMSO}-d_{6}\right): \delta 202.2$, 182.1, 148.7, 145.0, 135.3, 134.8, 132.7, 130.8, 126.3, 125.8, 122.8, 100.5, 60.5, 47.7, 42.4, 32.7, 22.1. Anal. calcd. for $\mathrm{C}_{17} \mathrm{H}_{18} \mathrm{~N}_{4} \mathrm{O}_{3}$ : C, 62.57; $\mathrm{H}, 5.56$; found: $\mathrm{C}, 62.71 ; \mathrm{H}, 5.49$.

After molecular structure characterization by infrared (IR), and ${ }^{1} \mathrm{H}$ and ${ }^{13} \mathrm{C} N M R$, the compounds were tested for ZIKV infection. The stock solutions were made at a concentration of $200 \mathrm{mM}$ with DMSO (Sigma-Aldric, San Luis, MO, USA). The compounds dilutions were made from the stock solution with Dulbecco's Modified Eagle Medium (DMEM) (Thermo Fisher Scientific, Waltham, MA, USA) reaching the maximum concentration of $0.8 \%$ DMSO.

A stock solution of the riboside nucleotide analog 6MMPr (Sigma-Aldrich, Louis, MO, USA) of $1 \mathrm{mM}$ was made in Milli-Q water and the compound was used as a positive control in antiviral tests. Dilutions of $60.50,30.25,15.13$ and $7.56 \mu \mathrm{M}$ were used according to the cytotoxicity methodology and $\mathrm{CC}_{20}$ values used by de Carvalho and co-workers [17].

\subsection{Cells and Viruses}

Vero cells (CCL-81) were used in all phases of the in vitro testing. The cultivation was performed with products from the company, Thermo Fisher Scientific. DMEM supplemented with $10 \%$ foetal bovine serum (FBS) and 1\% penicillin/streptomycin and incubated at $37^{\circ} \mathrm{C}$ and $5 \% \mathrm{CO}_{2}$ atmosphere on incubator Heracell VIOS 250i (Thermo Fisher Scientific).

A strain of ZIKV /H.sapiens/Brazil/PE243/2015 (abbreviated to ZIKV PE243; GenBank accession number KX197192.1) was used in antiviral tests. The viral stock was made in Vero cells and grown at $37^{\circ} \mathrm{C}$ and $5 \% \mathrm{CO}_{2}$ atmosphere. The endpoint dilution assay was the method used to obtain the $\mathrm{TCID}_{50} / \mathrm{mL}$ titer of this stock.

\subsection{Titration of Stock and Samples Virus}

96-well plates with $1 \times 10^{4}$ cell/well were used in this assay and prepared $24 \mathrm{~h}$ previously. Seven serial dilutions of the virus were prepared in DMEM $+2 \%$ FBS culture medium. After removing the culture medium from the plate, $50 \mu \mathrm{L}$ of each dilution was added to the wells in several repetitions. The plate was incubated at $37{ }^{\circ} \mathrm{C}$ and $5 \%$ atm $\mathrm{CO}_{2}$ for $1 \mathrm{~h}$. After this interval, each well of the plate received an additional $100 \mu \mathrm{L}$ of $\mathrm{DMEM}+2 \%$ FBS culture medium. The plate was incubated again, in the same parameters, for 5 days. Some columns of the plate were selected for use as a cell control (culture medium only, no virus). The reading was performed in an inverted optical microscope AE2000, Motic (Motic, Kowloon Bay, Hong Kong) counting positives wells by the presence of cytopathic effect and the determination of the sample title was performed with the aid of the Microsoft Office Excel program (Microsoft ${ }^{\circledR}$ Office, Redmond, WA, USA).

\subsection{Cytotoxicity Test with MTT Method}

96-well plates with $1 \times 10^{4}$ cell/well were used in this assay and prepared $24 \mathrm{~h}$ previously. The compounds were diluted in a 2:1 ratio so that a maximum of $0.8 \%$ DMSO was used. The concentrations used were 800, 400, 200, 100, 50, 25 and $12.5 \mu \mathrm{M}$. Dilutions were added to the wells in triplicate and incubated at $37^{\circ} \mathrm{C}$ and $5 \% \mathrm{CO}_{2}$ atmosphere. After 5 days, the wells were emptied and a $50 \mu \mathrm{L}$ of $1 \mathrm{mg} / \mathrm{mL}$ MTT (3-(4,5-dimethylthiazol-2-yl)2,5-diphenyltetrazolium bromide) (Sigma-Aldrich) solution was added, and the cells were incubated for 3-4 $\mathrm{h}$ for formation of formazan crystals through the mitochondria of viable cells. Then, medium was removed and $100 \mu \mathrm{L}$ DMSO was added to the wells to solubilize the formazan crystals. With the aid of an incubator Tecnal TE-420 (Tecnal Equipamentos Científicos, Piracicaba, São Paulo, Brazil), the plates were homogenized at 120 RPM at $37{ }^{\circ} \mathrm{C}$ and the optical densities were read at $570 \mathrm{~nm}$ on a spectrophotometer BioTekTM ELx800TM (BioTek Instruments, Winooski, VT, USA). The statistical analysis of these data revealed the values of $\mathrm{CC}_{20}$ and $\mathrm{CC}_{50}$, both in $\mu \mathrm{M}$, which was used in the screening test. 


\subsection{Screening Test}

The screening of the compounds was carried out with the $\mathrm{CC}_{20}$ value $(\mu \mathrm{M})$ to determine the most viable compounds for more detailed antiviral tests. 48-well plates with $2.5 \times 10^{4}$ cells/well were prepared with a previous $24 \mathrm{~h}$. The culture medium from the plate was removed and the wells were inoculated with a viral solution at MOI 0.1, except cell control (which received only culture medium $+2 \%$ FBS). During $2 \mathrm{~h}$ of incubation at $37^{\circ} \mathrm{C}$ and $5 \% \mathrm{CO}_{2}$ atmosphere, the solutions with the compounds are prepared with DMEM $+2 \%$ FBS. After incubation, the medium was discarded, and the wells were washed with 1X phosphate buffer solution (PBS). The solutions with the compounds were added to the wells, in triplicate, and then incubated for 5 days under the same conditions. After incubation, the supernatant from each well was collected and stored at $-80^{\circ} \mathrm{C}$. The samples were then titrated and analysed statistically.

\subsection{Pre-Treatment Activity}

To prepare, 48 -well plates with $2.5 \times 10^{4}$ cells/well were prepared $24 \mathrm{~h}$ previously. Compound $4 \mathbf{b}$ was diluted in a 2:1 ratio in culture medium with concentrations of $136.90 \mu \mathrm{M}$ $\left(\mathrm{CC}_{20}\right), 68.45 \mu \mathrm{M}\left(\mathrm{CC}_{20} / 2\right) 34.22 \mu \mathrm{M}\left(\mathrm{CC}_{20} / 4\right)$ and $17.11 \mu \mathrm{M}\left(\mathrm{CC}_{20} / 8\right)$. The dilutions were inoculated into the wells in triplicate and the cells incubated at $37{ }^{\circ} \mathrm{C}$ and $5 \% \mathrm{CO}_{2}$ atmosphere. After $1 \mathrm{~h}$, the culture medium with the compounds was removed and the wells were washed with $1 \mathrm{X}$ PBS. A ZIKV solution at MOI 0.1 was inoculated into the treated and control wells. The cells were again incubated for 5 days. The supernatants from the wells were collected and titrated.

\subsection{Post-Infection Activity}

48-well plates with $2.5 \times 10^{4}$ cells/well were prepared $24 \mathrm{~h}$ previously. A ZIKV solution at MOI 0.1 was inoculated into the wells and the cells incubated at $37^{\circ} \mathrm{C}$ and $5 \%$ $\mathrm{CO}_{2}$ atmosphere. After $2 \mathrm{~h}$, the culture medium was removed, and the wells were washed with 1X PBS. 2:1 dilution of $4 \mathbf{b}(136.90 \mu \mathrm{M}, 68.45 \mu \mathrm{M}, 34.22 \mu \mathrm{M}$ and $17.11 \mu \mathrm{M})$ and $6 \mathrm{MMPr}$ $(60.50 \mu \mathrm{M}, 30.25 \mu \mathrm{M}, 15.13 \mu \mathrm{M}$ and $7.56 \mu \mathrm{M})$ were added in triplicate. The cells were again incubated for $72 \mathrm{~h}$ and $120 \mathrm{~h}$. The supernatants from the wells were collected and titrated.

\subsection{Molecular Docking}

The coordinate structure of NSP3 (PDB: 6MH3) and NSP5 (PDB: 5U04) proteins were collected from RCSB website (https: / / www.rcsb.org, accessed on 10 February 2021). The NSP3 and NSP5 also known as helicase and RNA dependent RNA polymerase (RdRp) protein, respectively. The RdRp protein had several missing residues (Table S1), so missing loops were filled with the help of modeller software [29]. The best model was selected among 15 models based on ERRAT [30], PROSA [31], Verify3D [32], and PROCHECK [33] (Table S2). The computational work performed using Schrodinger software (Schrodinger release 2020-1 license dated 20 November 2020). Both protein structures were prepared to minimize the structural defects by using protein preparation wizard before docking studies [34-36]. Before docking compound $\mathbf{4 b}$ structure was also prepared by the Ligprep [35,37]. The Epik module of Schrodinger was used to predict the ionization states of compound $\mathbf{4 b}$ at $\mathrm{pH} 7 \pm 2$ as well as tautomers generated [38]. In-silico study was carried out under OPLS2005 forcefield.

\subsubsection{Molecular Docking of Designed Chemical Library}

The binding site of both the proteins was predicted by sitemap [39]. The best site was selected based on site score (Tables S3 and S4). The co-ordinate of binding site for RdRp protein includes $26.17,66.84$, and 103.42, while the helicase protein includes -5.54 , 2.84, and -6.55 . Compound $4 \mathrm{~b}$ was docked at XP precision to both the proteins in a site-specific manner using Glide module of Schrödinger suite [40]. The Van der Waals radii scaling factor and partial charge cut-off was 0.8 and 0.15 , employed for docking study, 
respectively. The binding free energy for both the complexes were also calculated by prime MMGBSA [41].

\subsubsection{Molecular Dynamics (MD) Simulation}

To validate the docking results, both the protein complexes of compound $4 \mathrm{~b}$ with helicase and RdRp protein were selected for $50 \mathrm{~ns}$ MD simulation [42]. These complexes were solvated in TIP3P [43] water model and $0.15 \mathrm{M} \mathrm{NaCl}$ to mimic a physiological ionic concentration. The stereo-chemical geometry of 5HGL protein residues was measured by Ramachandran map by procheck [33].

\subsection{Statistical Analysis}

After reading the optical densities of the cytotoxicity test revealed by the MTT method, the calculation of the cell viability percentage was performed in the Microsoft Office Excel 15 (Microsoft ${ }^{\circledR}$ Office) program using the following formula:

$$
\% \text { Viability }=\mathrm{OD}_{\text {sample }} \times 100 / \mathrm{OD}_{\text {cellular control }}
$$

The determination of the $\mathrm{CC}_{20}$ and $\mathrm{CC}_{50}$ values was obtained through the linear regression analysis of the $\mathrm{XY}$ graph generated by the values of the concentrations used in the test and the triplicate values of the viability. In the post-infection and pre-treatment tests, ANOVA and Dunnett tests were used, considering $p>0.05$ as the minimum significance value. All tests were performed in GraphPad Prism v.6.0 program (GraphPad Software, Inc., San Diego, CA, USA).

\section{Conclusions}

Heterocyclic compounds have several activities recorded in the literature. The triazole and naphthoquinone groups have already been reported with antiviral activity against the Zika virus, while the phthalimide group has no previously reported activity against the virus. Fourteen compounds were tested in this study. In the cytotoxicity test, the $\mathrm{CC}_{20}$ $(8.87-527.20 \mu \mathrm{M})$ and $\mathrm{CC}_{50}(38.01-1189.00 \mu \mathrm{M})$ values were quite diverse, showing high to low values, but all of them were feasible for the antiviral screening. Compound $\mathbf{3 b}$ stood out with the highest values of $\mathrm{CC}_{20}$ and $\mathrm{CC}_{50}$. The screening revealed compound $\mathbf{4 b}$ as the most active against ZIKV, and the results confirm a post-infectious antiviral activity. Docking results coupled with score, XP Gscore and binding free energy suggested compound $4 \mathrm{~b}$ with strong binding affinity for NS5 RdRp protein target of ZIKV, which was further supported by MD simulations. However, validation experiments are necessary before concluding the possible target for the hit compound $4 \mathbf{b}$, which could be a part of our future investigations. Lead optimization, in conjunction with in-silico analysis, could deliver new versions of the molecule with significantly increased activity against ZIKV. In addition, in vivo tests will be important to confirm the efficacy of these promising molecules in adequate ZIKV animal models.

Supplementary Materials: The following are available online. Figure S1: Graphical results for cytotoxicity assay of triazole derivates in Vero cells, Table S1: Missing residues in RdRp (5U04) protein, Table S2: Model generated after filling loops for RdRp protein (5U04), Figure S2: Ramachandran map of top scored modeled RdRp (5U04) protein, Figure S3: MD simulation of $4 \mathbf{b}$-helicase (6MH3) complex. (A) Ligand RMSF-fluctuations of each atom of compound $4 \mathbf{b}$ with respect to protein; (B) Histogram plot showed interacting residues with compound $\mathbf{4 b}$ during MD simulation (H-bond: green, hydrophobic: grey, salt bridge interaction: pink, and water bridge interaction: blue), Figure S4: Ramachandran map after MD Simulation for $\mathbf{4 b}$-RdRp (5U04) complex, Table S3: Site score of predicted binding site by Site Map for helicase protein (6MH3), Table S4: Site score of predicted binding site by Site Map for RdRp protein (5U04), Figure S5: ${ }^{1} \mathrm{H}$ NMR of compound 5a, Figure S6:

${ }^{13} \mathrm{C}$ NMR of compound $\mathbf{5 a}$. 
Author Contributions: Conceptualization, R.N.d.O., L.J.P., B.R. and G.S.; methodology, W.M.D., V.N.M.d.O., D.A.L.S., P.P.S.; writing—original draft preparation, W.M.D.; writing-review and editing, R.N.d.O., B.R. and L.J.P.; supervision, project administration, and funding acquisition, R.N.d.O. and L.J.P. All authors have read and agreed to the published version of the manuscript.

Funding: The work in Pena's lab is funded by the Fiocruz Inova Program, IDCR-Canada, and Foundation for Science and Technology of Pernambuco-FACEPE (grant number APQ-0560-2.12/19). The authors are grateful to National Council for Scientific and Technological Development-CNPq [grant numbers PQ 301308/2017-9 and PQ 310956/2019-6]. This study was financed in part by the Coordenação de Aperfeiçoamento de Pessoal de Nível Superior-Brasil-CAPES finance code 001.

Institutional Review Board Statement: Vero cells were obtained from the Fiocruz Pernambuco Laboratory of Virology repository.

Informed Consent Statement: Not applicable.

Data Availability Statement: The authors declare no competing financial interest. The study is done on Schrodinger maestro 2020-1 version platform. This software can be downloaded from https: / / www.schrodinger.com/. Another software, Desmond Release 2020-1 was used for molecular dynamics simulations is freely available and can be downloaded from "https: / www.deshawresearch. com/resources_desmond.html". All the protein structure, ligand-protein complex file, and MD simulation data are made available on Github https:/ / github.com/premprakash11241/SearchingAnti-Zika-Virus-Activity-in-1H-1-2-3-Triazole-Based-Compounds.

Acknowledgments: We thank Jessica C. F. do Nascimento for critically reviewing the manuscript. BR and PPS acknowledge the administration of Hansraj College, University of Delhi for infrastructural support. LJP acknowledge Oswaldo Cruz Foundation (Fiocruz) for infrastructural support.

Conflicts of Interest: The authors declare no conflict of interest.

Sample Availability: Samples of the compounds 1-7 are available from the authors.

\section{References}

1. Guedes, D.R.; Paiva, M.H.; Donato, M.M.; Barbosa, P.P.; Krokovsky, L.; Rocha, S.W.D.S.; LA Saraiva, K.; Crespo, M.M.; Rezende, T.M.; Wallau, G.L.; et al. Zika virus replication in the mosquito Culex quinquefasciatus in Brazil. Emerg. Microbes Infect. 2017,6 , e69. [CrossRef]

2. Hu, Y.; Sun, L. Systematic Analysis of Structure Similarity between Zika Virus and Other Flaviviruses. ACS Infect. Dis. 2019, 5, 1070-1080. [CrossRef]

3. Dick, G.W.A.; Kitchen, S.F.; Haddow, A.J. Zika Virus (I). Isolations and serological specificity. Trans. R. Soc. Trop. Med. Hyg. 1952, 46, 509-520. [CrossRef]

4. Duffy, M.R.; Chen, T.-H.; Hancock, W.T.; Powers, A.M.; Kool, J.L.; Lanciotti, R.S.; Pretrick, M.; Marfel, M.; Holzbauer, S.; Dubray, C.; et al. Zika Virus Outbreak on Yap Island, Federated States of Micronesia. N. Engl. J. Med. 2009, 360, 2536-2543. [CrossRef] [PubMed]

5. Cao-Lormeau, V.-M.; Roche, C.; Teissier, A.; Robin, E.; Berry, A.-L.; Mallet, H.-P.; Sall, A.A.; Musso, D. Zika virus, French Polynesia, South Pacific, 2013. Emerg. Infect. Dis. 2014, 20, 1085-1086. [CrossRef] [PubMed]

6. Campos, T.D.L.; Durães-Carvalho, R.; Rezende, A.M.; De Carvalho, O.V.; Kohl, A.; Wallau, G.L.; Pena, L.J. Revisiting key entry routes of human epidemic arboviruses into the mainland americas through large-scale phylogenomics. Int. J. Genom. 2018, 2018, 6941735. [CrossRef] [PubMed]

7. Lowe, R.; Barcellos, C.; Brasil, P.; Cruz, O.G.; Honório, N.A.; Kuper, H.; Carvalho, M.S. The zika virus epidemic in brazil: From discovery to future implications. Int. J. Environ. Res. Public Health 2018, 15, 96. [CrossRef] [PubMed]

8. Ferreira, M.L.B.; Albuquerque, M.D.F.P.M.D.; de Brito, C.A.A.; França, R.F.D.O.; Moreira, Á.J.P.; Machado, M.; Íris, D.M.; Melo, R.D.P.; Medialdea-Carrera, R.; Mesquita, S.D.; et al. Neurological disease in adults with Zika and chikungunya virus infection in Northeast Brazil: A prospective observational study. Lancet Neurol. 2020, 19, 826-839. [CrossRef]

9. Cardona-Ospina, J.A.; Henao-SanMartin, V.; Acevedo-Mendoza, W.F.; Nasner-Posso, K.M.; Martínez-Pulgarin, D.F.; RestrepoLópez, A.; Valencia-Gallego, V.; Collins, M.H.; Rodriguez-Morales, A.J. Fatal Zika virus infection in the Americas: A systematic review. Int. J. Infect. Dis. 2019, 88, 49-59. [CrossRef]

10. Rasmussen, S.A.; Jamieson, D.J.; Honein, M.A.; Petersen, L.R. Zika Virus and Birth Defects-Reviewing the Evidence for Causality. N. Engl. J. Med. 2016, 374, 1981-1987. [CrossRef]

11. Akhtar, J.; Khan, A.A.; Ali, Z.; Haider, R.; Yar, M.S. Structure-activity relationship (SAR) study and design strategies of nitrogencontaining heterocyclic moieties for their anticancer activities. Eur. J. Med. Chem. 2017, 125, 143-189. [CrossRef] 
12. Li, C.; Zhu, X.; Ji, X.; Quanquin, N.; Deng, Y.Q.; Tian, M.; Aliyari, R.; Zuo, X.; Yuan, L.; Afridi, S.K.; et al. Chloroquine, a FDA-approved Drug, Prevents Zika Virus Infection and its Associated Congenital Microcephaly in Mice. EBioMedicine 2017, 24, 189-194. [CrossRef] [PubMed]

13. Bullard-Feibelman, K.M.; Govero, J.; Zhu, Z.; Salazar, V.; Veselinovic, M.; Diamond, M.S.; Geiss, B.J. The FDA-approved drug sofosbuvir inhibits Zika virus infection. Antivir. Res. 2017, 137, 134-140. [CrossRef] [PubMed]

14. Kim, J.-A.; Seong, R.-K.; Kumar, M.; Shin, O.S. Favipiravir and ribavirin inhibit replication of Asian and African strains of zika virus in different cell models. Viruses 2018, 10, 72. [CrossRef]

15. Soto-Acosta, R.; Jung, E.; Qiu, L.; Wilson, D.; Geraghty, R.; Chen, L. 4,7-Disubstituted 7H-Pyrrolo[2,3-D]Pyrimidines and Their Analogs As Antiviral Agents Against Zika Virus. Molecules 2021, 26, 3799. [CrossRef]

16. Baz, M.; Boivin, G. Antiviral agents in development for zika virus infections. Pharmaceuticals 2019, 12, 101. [CrossRef]

17. De Carvalho, O.V.; Félix, D.M.; de Mendonça, L.R.; de Araújo, C.M.C.S.; Franca, R.F.D.O.; Cordeiro, M.T.; Júnior, A.S.; Pena, L.J. The thiopurine nucleoside analogue 6-methylmercaptopurine riboside (6MMPr) effectively blocks Zika virus replication. Int. J. Antimicrob. Agents 2017, 50, 718-725. [CrossRef] [PubMed]

18. Brzuska, G.; Pastuch-Gawolek, G.; Krawczyk, M.; Szewczyk, B.; Krol, E. Anti-tick-borne encephalitis virus activity of novel uridine glycoconjugates containing amide or/and 1,2,3-triazole moiety in the linker structure. Pharmaceuticals 2020, 13, 460. [CrossRef] [PubMed]

19. De Oliveira, V.N.M.; Moura, C.F.D.A.; Peixoto, A.D.S.; Ferreira, V.P.G.; Araújo, H.M.; Pimentel, L.M.L.M.; Pessoa, C.D.Ó.; Nicolete, R.; dos Anjos, J.V.; Sharma, P.P.; et al. Synthesis of alkynylated 1,2,4-oxadiazole/1,2,3-1H-triazole glycoconjugates: Discovering new compounds for use in chemotherapy against lung carcinoma and Mycobacterium tuberculosis. Eur. J. Med. Chem. 2021, $220,113472$. [CrossRef] [PubMed]

20. Da Silva, G.B.; Guimarães, B.M.; Assis, S.P.O.; Lima, V.L.M.; De Oliveira, R.N. Ultrasound-Assisted Synthesis of 1-N- $\beta-D-$ Glucopyranosyl-1H-1,2,3-triazole Benzoheterocycles and their Anti-Inflammatory Activities. J. Braz. Chem. Soc. 2013, 24, 914-921. [CrossRef]

21. Gonzaga, D.; Gomes, R.; Marra, R.; Da Silva, F.; Gomes, M.; Ferreira, D.; Santos, R.; Pinto, A.; Ratcliffe, N.A.; Cirne-Santos, C.; et al. Inhibition of Zika virus replication by synthetic bis-naphthoquinones. J. Braz. Chem. Soc. 2019, 30, 1697-1706. [CrossRef]

22. Lima, Â.; Teixeira, R.; Silva, B.; Siqueira, R.P.; Silva, I.; Santos, E.; Fernandes, M.C.; Gonçalves, V.; Bressan, G.; Mendes, T.; et al. Síntese e avaliação das atividades fotoprotetora, citotóxica e antiviral contra o Zika virus de derivados triazólicos da benzofenona. Quim. Nova 2019, 42, 473-484. [CrossRef]

23. Aguiar, D.F.; Dutra, L.L.A.; Dantas, W.M.; Carvalho, G.; Lemes, R.P.G.; Pessoa, C.D.Ó.; Paier, C.R.K.; Araujo, P.; Araujo, E.; Pena, L.J.; et al. Synthesis, Antitumor and Cytotoxic Activity of New Adamantyl O-Acylamidoximes and 3-Aryl-5-Adamantane-1,2,4Oxadiazole Derivatives. ChemistrySelect 2019, 4, 9112-9118. [CrossRef]

24. De Oliveira, V.N.M.; Dos Santos, F.G.; Ferreira, V.P.G.; Araújo, H.M.; Pessoa, C.D.Ó.; Nicolete, R.; Oliveira, R. Focused microwave irradiation-assisted synthesis of N-cyclohexyl-1,2,4-oxadiazole derivatives with antitumor activity. Synth. Commun. 2018, 48, 2522-2532. [CrossRef]

25. De Oliveira, R.N.; Melo, V.N.; Dantas, W.M.; Camara, C.A. Synthesis of 2,3-unsaturated alkynyl O-glucosides from tri-Oacetyl-d-glucal by using montmorillonite K-10/iron(III) chloride hexahydrate with subsequent copper(I)-catalyzed 1,3-dipolar cycloaddition. Synthesis 2015, 47, 3529-3541. [CrossRef]

26. De Oliveira, R.; Da Silva, M.; Da Silva, M.; Melo, V.; Valença, W.; Da Paz, J.; Camara, C. New strategies for molecular diversification of 2-[Aminoalkyl-(1H-1,2,3-Triazol-1- yl)]-1,4-naphthoquinones using click chemistry. J. Braz. Chem. Soc. 2017, 28, 681-688. [CrossRef]

27. Guimarães, T.T.; Pinto, M.D.C.F.; Lanza, J.S.; Melo, M.N.; Neto, R.M.; de Melo, I.M.; Diogo, E.B.; Ferreira, V.; Camara, C.; Valença, W.O.; et al. Potent naphthoquinones against antimony-sensitive and -resistant Leishmania parasites: Synthesis of novel $\alpha$ - And nor- $\alpha$-lapachone-based 1,2,3-triazoles by copper-catalyzed azide-alkyne cycloaddition. Eur. J. Med. Chem. 2013, 63, 523-530. [CrossRef] [PubMed]

28. Holanda, V.N.; da Silva, W.V.; Nascimento, P.H.D.; Silva, S.R.B.; Filho, P.E.C.; Assis, S.P.D.O.; da Silva, C.A.; de Oliveira, R.N.; de Figueiredo, R.C.B.Q.; Lima, V.L.D.M. Antileishmanial activity of 4-phenyl-1-[2-(phthalimido-2-yl)ethyl]-1H-1,2,3-triazole (PT4) derivative on Leishmania amazonensis and Leishmania braziliensis: In silico ADMET, in vitro activity, docking and molecular dynamic simulations. Bioorg. Chem. 2020, 105, 104437. [CrossRef] [PubMed]

29. Webb, B.; Sali, A. Comparative protein structure modeling using MODELLER. Curr. Protoc. Bioinforma. 2016, 54, 5.6.1-5.6.37. [CrossRef] [PubMed]

30. Colovos, C.; Yeates, T.O. Verification of protein structures: Patterns of nonbonded atomic interactions. Protein Sci. 1993, 2, 1511-1519. [CrossRef]

31. Wiederstein, M.; Sippl, M.J. ProSA-web: Interactive web service for the recognition of errors in three-dimensional structures of proteins. Nucleic Acids Res. 2007, 35, W407-W410. [CrossRef]

32. Lüthy, R.; Bowie, J.U.; Eisenberg, D. Assessment of protein models with three-dimensional profiles. Nature 1992, $359,83-85$. [CrossRef] [PubMed]

33. Laskowski, R.A.; MacArthur, M.W.; Moss, D.S.; Thornton, J.M. PROCHECK: A program to check the stereochemical quality of protein structures. J. Appl. Crystallogr. 1993, 26, 283-291. [CrossRef] 
34. Madhavi Sastry, G.; Adzhigirey, M.; Day, T.; Annabhimoju, R.; Sherman, W. Protein and ligand preparation: Parameters, protocols, and influence on virtual screening enrichments. J. Comput. Aided. Mol. Des. 2013, 27, 221-234. [CrossRef] [PubMed]

35. Kumar, S.; Sharma, P.P.; Shankar, U.; Kumar, D.; Joshi, S.K.; Pena, L.; Durvasula, R.; Kumar, A.; Kempaiah, P.; Poonam; et al. Discovery of New Hydroxyethylamine Analogs against 3CLproProtein Target of SARS-CoV-2: Molecular Docking, Molecular Dynamics Simulation, and Structure-Activity Relationship Studies. J. Chem. Inf. Model. 2020, 60, 5754-5770. [CrossRef] [PubMed]

36. Schrödinger Release 2020-1: Protein Preparation Wizard; Epik; Prime, S., LLC, New York, NY, 2016; Impact, Schrödinger, LLC, New York, NY, 2016; Prime, Schrödinger, LLC, New York, NY. 2020.

37. Schrödinger Release 2020-1: LigPrep, S., LLC, New York, NY. 2020.

38. Schrödinger Release 2020-1: Epik, S., LLC, New York, NY. 2020.

39. Schrödinger Release 2020-1: SiteMap, S., LLC, New York, NY. 2021.

40. Schrödinger Release 2020-1: Glide, S., LLC, New York, NY. 2020.

41. Schrödinger Release 2020-1: Prime, S., LLC, New York, NY. 2020.

42. Schrödinger Release 2020-1: Desmond Molecular Dynamics System, D.E.S.R., New York, NY, 2020. Maestro-Desmond Interoperability Tools, Schrödinger, New York, NY. 2020.

43. Mark, P.; Nilsson, L. Structure and dynamics of the TIP3P, SPC, and SPC/E water models at 298 K. J. Phys. Chem. A 2001, 105, 9954-9960. [CrossRef] 